\title{
Geotechnical Investigation and Numerical Analysis of Rockfall in South Coast of Gunung Kidul Regency
}

\author{
Odhi Attabik Illiyin \\ PT. PP (Persero) Tbk, Jakarta, INDONESIA \\ odhi.attabik1@gmail.com \\ Fikri Faris \\ Department of Civil and Environmental Engineering, Universitas Gadjah Mada, Yogyakarta, INDONESIA \\ fikri.faris@ugm.ac.id
}

\begin{abstract}
On $17^{\text {th }}$ of June 2015, rockfall occurred on the South Coast at Gunung Kidul Regency taking a few casualties. The preliminary investigation results concluded that many cliffs on the South Coast are dangerous, and there is a potential that similar events might happen in the future. Therefore, geotechnical investigation in order to plan mitigation action is necessary. Field investigations, laboratory work, and numerical modeling were employed in this study, focusing on Sadranan beach where the incident happened. Rock slope stability analyses by means two-dimensional finite element in both static and seismic conditions were conducted. The investigation results show that both biological decay and wave erosion influence the rock slope instability. Moreover, the infilling material in rock joint has considerable effect on the stability of the slope. However, the results from numerical simulation suggested that potential failure was originating from the intact rock body instead of the plane of discontinuities. In the seismic condition, the slopes are more vulnerable and further mitigation action should be considered in the future.
\end{abstract}

Keywords: Slope rock, Barton criteria, discontinuity plan, slope modeling

\section{INTRODUCTION}

On $17^{\text {th }}$ of June 2015 , rockfall has occurred on the South Coast at Gunung Kidul Regency, a few casualties caused by this event. The investigation results of the Landslide Team from the Volcanology and Geological Disaster Mitigation Centre of the Ministry of Energy and Mineral Resources (MEMR) concluded that the cliff on the South Coast is dangerous, and there is a potential that similar events might happen in the future (Illiyin, 2017). Therefore, to reduce the risk of having another rockfall disaster, a mitigation effort with geotechnical approach is needed.

The proposed research is planned to use a numerical approach to analyze the rockfall potential on the vulnerable points around the South Coast. The fundamental stages of the research are field investigation, laboratory testing, and numerical analysis using Plaxis finite element program.

The results are expected to be able to acknowledge the deformation behavior and the rock mass tension and can be utilized for the calculation of geotechnical mitigation effort on the rock cliff.

\section{RESEARCH BACKGROUND}

The Gunung Kidul South Coast area has been known as a tourist destination with a lot of steep rock cliffs, but the high intensity of sea waves and corrosion of rock mass become the causes of instability and vulnerability to the abrasion. Rockfall that often occurs in this area also becomes a threat to the visiting tourists (Yuwono, 2015a).

On June $17^{\text {th }}, 2015$, rockfall from cliff in Sadranan Beach fell on a number of tourists as seen in Figure 1. The incident occurred at 15:00 Indonesia Western Time (UTC+7) claimed four casualties and injured two people (Yuwono, 2015b). Founded with the background of the incident, MEMR had conducted investigations on the area around Sadranan Beach. The investigations concluded that the cliffs on the beach are generally dangerous, and it is feared that similar disaster could happen again in the future (Yuwono, 2015a).

Review on the general risk of rockfall vulnerability in Gunung Kidul South Coast was conducted by Jamikotomo et al. (2015) with Modified Rockfall Hazard Rating System semi quantitative method. With this method, it is concluded that beaches in the area have the high rockfall risks. However, the research of Jatmikotomo et al. (2015) has not probe deeper into 
geotechnical prevention of the rockfall risk and its susceptibility to earthquakes. The proposed research is the first step in a series of numerical studies to support geotechnical mitigation through field investigation and laboratory testing, and also numerical analysis that considers the possible seismic forces in Gunung Kidul area

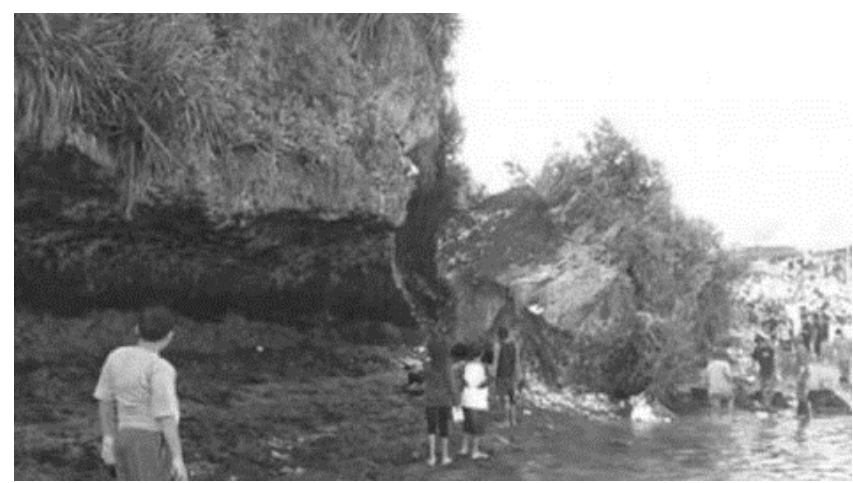

Figure 1. The rockfall incident on 17th of June, 2015 (Kusuma, 2015)

\section{ROCKFALL RISK ASSESSMENT}

By kinematic trait, the rockfall can be divided into two groups: falling and topple (Varnes, 1978). Some of the many factors that able to increase the landslideinducing shear stress are the erosion by waves and the corrosion (Abramson et al., 1996). According to Jatmikotomo et al. (2015), the factors that affect the susceptibility of rocks on beach area are structure of the rocks, its dimension, tilt level of the slope, corrosion degree, and abrasion.

General studies on rockfall have been done in various countries. Canuti et al. (2008) assessed the rockfall at cliffs in Pitigliano area (Italy). The kinematical assessment was supported by the digital elevation model that was derived from surveys using laser scanning. The research was aimed to reassess the rockfall risk on a cliff-top settlement, and to implement a surveillance system for cliff instability. Peng et al. (2008) inventoried rock mass on cliff alongside the valley of China's Three Gorges River, in relation with risk mapping of landslide and rockfall. It was concluded from this research that the biggest factors that control cliff stability of rock mass in Three Gorges River are the layering and structure of the rock mass.

On the subject of the assessment of rockfall risk at beach coast's rock cliff, Yousseff et al. (2009) applied remote sensing to the area of Sharm El-Sheikh in South Sinai, Egypt. In the research, the risked areas have been identified and the vulnerability map of the rockfall was made as reference for the future mitigation effort.
Special research on the state of the cliff in Gunung Kidul South Coast was done by Jatmikotomo et al. (2015), by using the method of Modified Rockfall Hazard Rating System developed by Budetta (2004). This method is a semi-quantitative method with some parameters, which is slope mass rating (SMR), block size, clod volume, number of the exposed lives, and rain precipitation. This research becomes the basis for assigning the location that will be investigated further, in the matter of rock strengths, rock mass collapse criteria, and numerical analysis of the stability.

\section{RESEARCH METHODOLOGY}

The objective of the research is the South Coast of Gunung Kidul, focused on rock cliffs with high level of susceptibility, as on the Sadranan Beach, in order to obtain the rock type verification. The study location and the rock failure case are shown in Figure 2, and Figure 3, respectively.

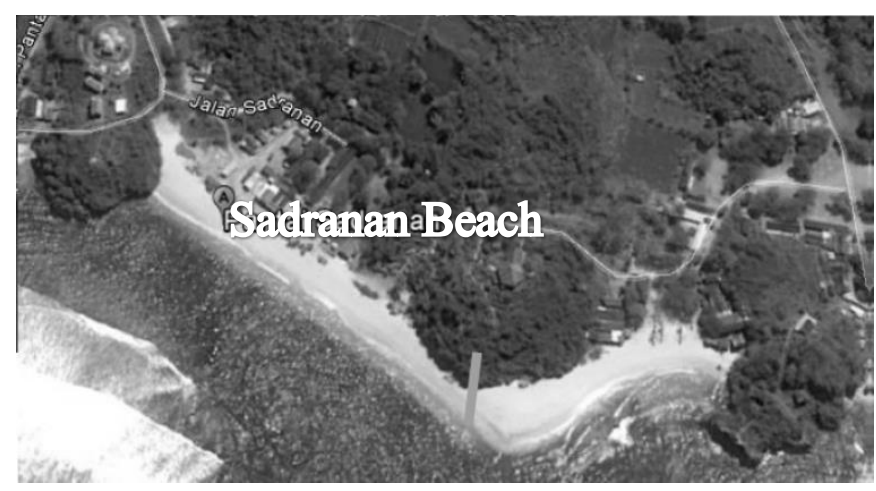

Figure 2. Research location

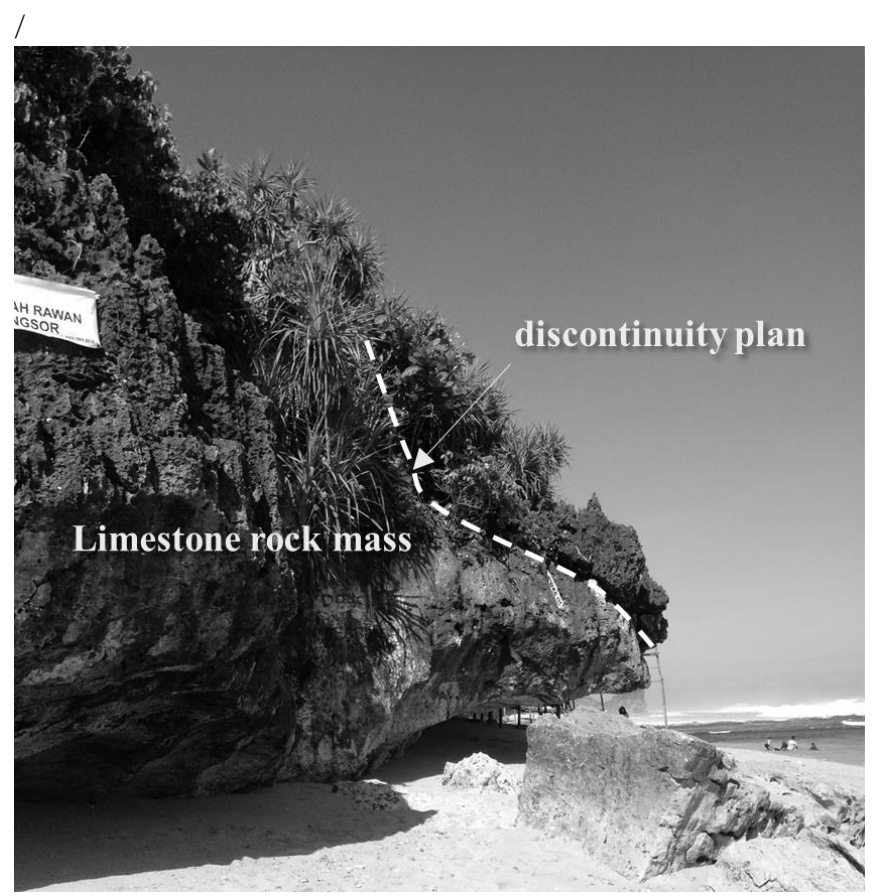

Figure 3. Potential slope failure in Sadranan Beach 
The equipment which used to test the strength of the intact rock is concrete compression strength test equipment and rocks shear strength test equipment. Whereas the numerical analysis will be using Plaxis version 8 .

Field investigation includes the preliminary investigation and advanced investigation. A preliminary investigation is intended to determine the location needed to collect the rock cliff dimensional data. The advanced investigation itself will be comprised of rock slope dimensional measurement, sampling, and rock strength measurement using the Schmidt hammer.

The laboratory tests included rock properties index test and rock mechanical test. The rock properties index tests consisted of the specific gravity test, water content, porosity, and specific weight. Whereas the rock mechanical test consisted of rock unconfined compression test and rock shear strength test.

For numerical analysis purpose, the failure criteria of the material should be reliably determined. This research using both Hoek-Brown 2002 and Barton failure criteria for rock mass and discontinuity plan, respectively. The Hoek-Brown criteria of rock mass have been widely used and applied in many constructions works on rock mass (Hoek et al., 2002). This criterion is a developed version of the previous Hoek-Brown criteria (starting from 1980). The new criteria well accommodate the Mohr-Coloumb parameter equivalent on soil shear stress and cohesion of the rock mass. In general, the Hoek Brown criteria follow the equation 1, namely:

$\sigma_{1}^{\prime}=\sigma_{3}^{\prime}+\sigma_{c i}\left(m \frac{\sigma_{3}^{\prime}}{\sigma_{c i}}+s\right)^{a}$

where $\sigma_{1}{ }^{\prime}$ and $\sigma_{3}{ }^{\prime}$ is the major and minor effective stresses. $\sigma_{\mathrm{ci}}{ }^{\prime}$ is the uniaxial earth pressure from intact rock, and $m, s$ and $a$ are material constants with $s=1$ and $a=0.5$ for intact rock. On the case of rock mass, the notation $m$ is replaced with notation $m_{b}$, whereas for rock intact notation $m$ is replaced with notation $m_{i}$. The relation between $m_{i}$ and $m_{b}$ obtained by equation:

$m_{b}=m_{i} \exp \left(\frac{G S I-100}{28-14 D}\right)$

with $m_{b}$ is the reduced value of the material constants $m_{i}$. Geological Strength Index (GSI) value is an index that was developed by Hoek et al. (1992), as a rock mass qualification that matches the developed criteria. Meanwhile, $D$ is a factor that depends on the interference level, due to either construction method on tunnel or rock slope. For value $s$ and $a$ on rock mass, is calculated with equation:

$s=\exp \left(\frac{G S I-100}{9-3 D}\right)$

$a=\frac{1}{2}+\frac{1}{6}\left(e^{-G S I / 15}-e^{-20 / 3}\right)$

Barton criterion is the empirical formulation that predicts the maximum shear strength of discontinuity plan. The Barton failure criterion is as follows:

$\tau_{p}=\sigma_{n} \tan \left(J R C \log _{10}\left(\frac{J C S}{\sigma_{n}}\right)+\phi_{r}\right)$

where $\tau_{p}$ is peak shear strength (MPa), $\sigma_{n}$ is applied normal stress (MPa), JRC is joint roughness coefficient, JCS is joint compressive strength (MPa), and $\phi_{\mathrm{r}}$ is residual friction angle (degree).

To calculate safety factor from Barton criterion, the following equation is used:

$$
F_{S}=\frac{\tau_{p}}{W \sin \alpha+F \cos \alpha}
$$

where $W$ is the weight of the sliding block, $F$ is the dynamic load assumed as pseudo-static force and $\alpha$ is the average inclination of the sliding block. The variables are indicated in Figure 4. The Barton criterion safety factor analysis will limitedly consider the block as the sliding material, while the whole structure of the hanging rock will be numerically analyzed by using Plaxis.

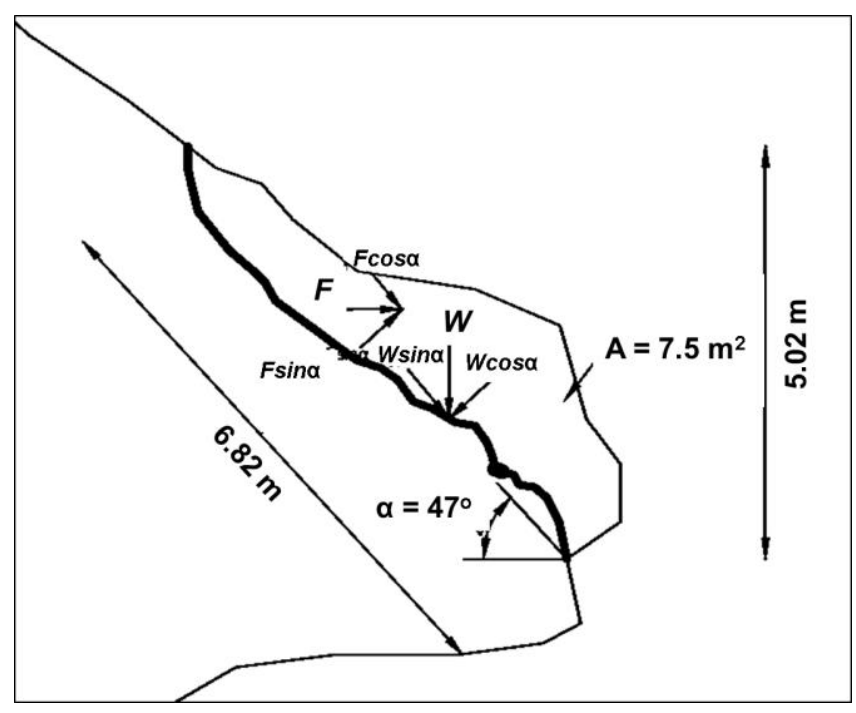

Figure 4. Forces acting on sliding block in the Barton criterion safety factor analysis 
The numerical analysis conducted by using finite element procedure of Plaxis 8.2, resulted in the deformation and stress on rock slope. For the safety factor calculation, Plaxis used strength reduction method instead limit equilibrium analysis.

Table 1. The properties of rock slope material

\begin{tabular}{|c|c|c|c|}
\hline Properties & & Lime stone & $\begin{array}{l}\text { Infilling } \\
\text { material }\end{array}$ \\
\hline Material Model & Model & $\begin{array}{l}\text { Mohr- } \\
\text { Coulomb }\end{array}$ & $\begin{array}{l}\text { Mohr- } \\
\text { Coulomb }\end{array}$ \\
\hline $\begin{array}{l}\text { Type of material } \\
\text { behavior }\end{array}$ & Type & undrained & Drained \\
\hline $\begin{array}{l}\text { Soil unit weight } \\
\text { above phreatic } \\
\text { level *) }\end{array}$ & $\gamma_{d r y}\left(\mathrm{kN} / \mathrm{m}^{3}\right)$ & 22.75 & 16 \\
\hline $\begin{array}{l}\text { Soil unit weight } \\
\text { below phreatic } \\
\text { level *) }\end{array}$ & $\gamma_{\text {sat }}\left(\mathrm{kN} / \mathrm{m}^{3}\right)$ & 23.43 & 18 \\
\hline $\begin{array}{l}\text { Young's } \\
\text { modulus } \\
(\text { constant }) *)\end{array}$ & $E_{e f f}\left(\mathrm{kN} / \mathrm{m}^{2}\right)$ & $20,554.12$ & 10,000 \\
\hline Poisson's ratio & $v$ & 0.3 & 0.3 \\
\hline $\begin{array}{l}\text { Cohesion } \\
(\text { constant }) * *)\end{array}$ & $c_{e f f}\left(\mathrm{kN} / \mathrm{m}^{2}\right)$ & 0.02 & 5 \\
\hline $\begin{array}{l}\text { Friction angle } \\
* *)\end{array}$ & $\phi\left(^{\circ}\right)$ & 48.07 & 25 \\
\hline $\begin{array}{l}\text { Permeability } \\
* * *)\end{array}$ & $\begin{array}{l}k_{x}, k_{y} \\
(\mathrm{~m} / \text { day })\end{array}$ & $8.64 \times 10^{-6}$ & 0.001 \\
\hline
\end{tabular}

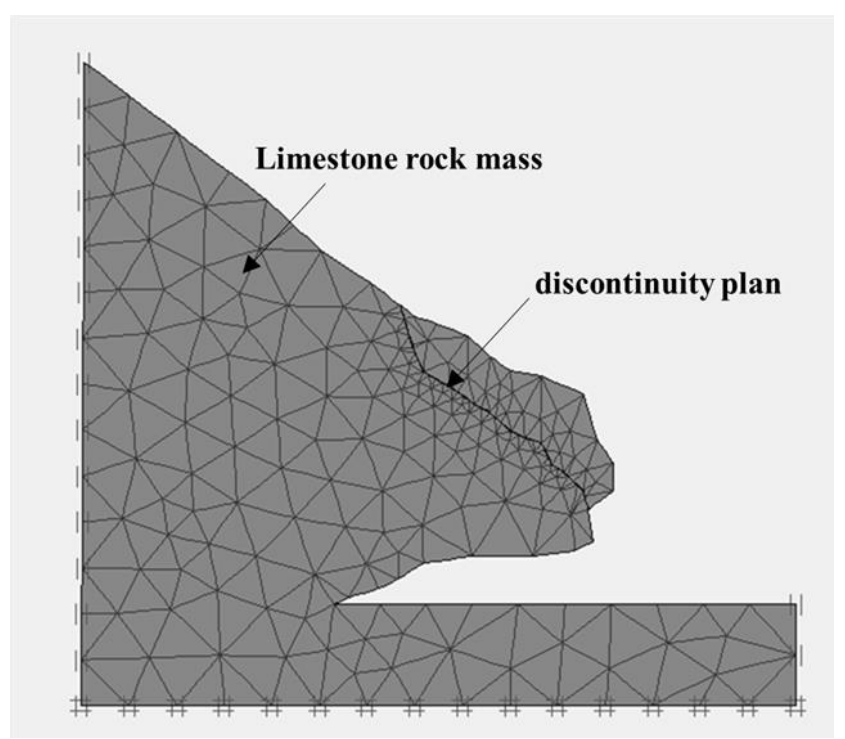

Figure 5. Elements configuration in Plaxis analysis

The results strength parameter and properties of the rock material from field and laboratory strength test are shown in Table 1. The materials of the rock cliff consisted of intake carbonate rock and deteriorated carbonate rock. Although the infilling material could not be observed in the discontinuity plan, in this research, it was assumed to be present as weathered carbonate rock. Both materials have contrast shear strength, whereas infilling material has only $50 \%$ strength that of carbonate rock. It suggested that the presence of infilling in discontinuity plan could highly affect the stability the rock slope. In the numerical analysis using Plaxis, the infilling material was modeled as soil thin interface element in the discontinuity plan (Figure 5).

\section{RESULTS AND DISCUSSION}

Results from the numerical analysis using finite element program, Plaxis, suggested that the rock slope are safe during static condition. However, the generation of dynamic load into the model makes the slope becomes unstable. Figure 6 shows the displacement in the rock slope model on unfilled condition. The mean stresses diagram suggested that the compression stresses concentrated at the lower part and the tension at the upper part (Figure 7).The figure suggested that potential failure is originating from the intact rock body instead of the plane of discontinuities. The notch structure of the slope fully controls the stress strain behavior. Therefore, the mitigation action should consider the whole notch structure and the rock joint as well.

The Barton calculation only analyzed the discontinuity plan where the infilling exist for stability analysis whereas Plaxis 8.2 considering the whole structure of hanging rock slope to calculate safety factor. Consequently, the result from Table 2 shows that in Barton analysis, the infilling shear strength contribution is influencing the safety factor of the slope. In the other hand, the safety factor resulted from Plaxis 8.2 calculation was constant in varying infilling shear strength contribution.

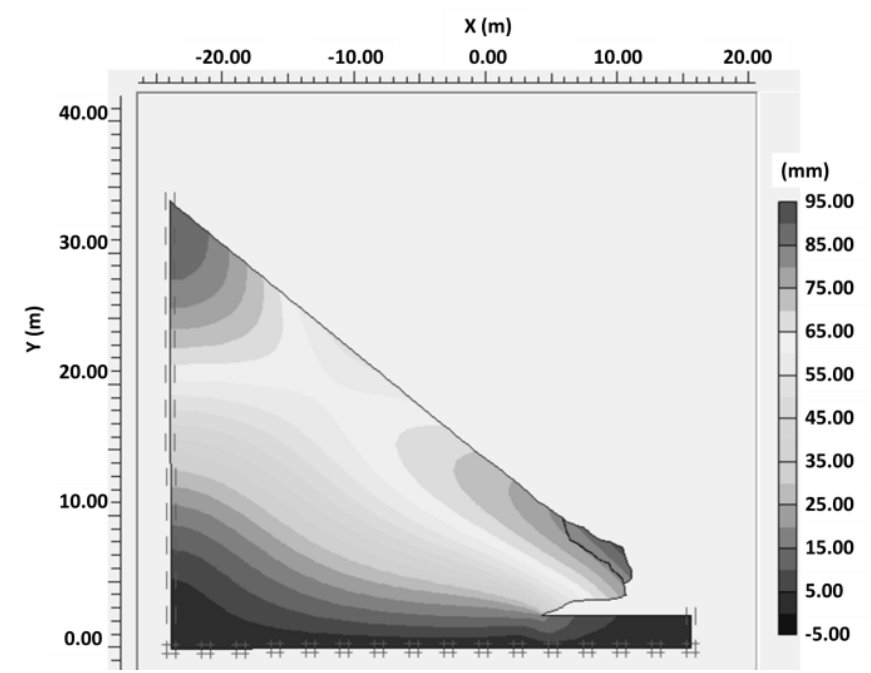

Figure 6. Displacement in the rock slope model on unfilled condition for dynamic condition 


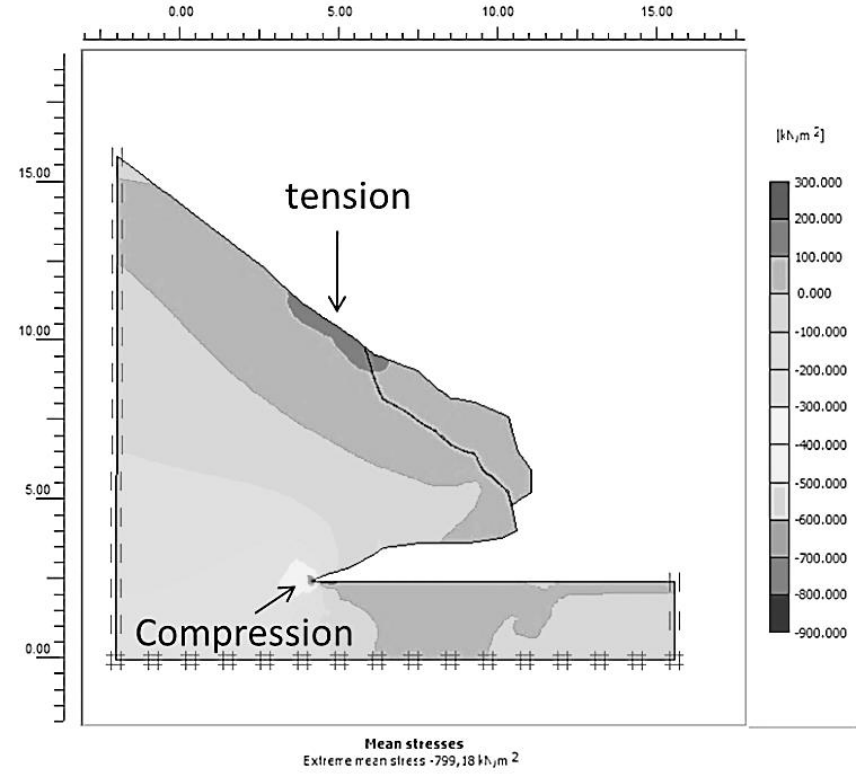

Figure 7. Mean stresses diagram

Table 2. Safety factor from Barton formula and Plaxis 8.2 calculation

\begin{tabular}{|c|c|c|c|c|}
\hline \multirow{2}{*}{ Infilling (\%) } & \multicolumn{4}{|c|}{ Static condition } \\
\hline & \multicolumn{2}{|c|}{ Barton criterion } & \multicolumn{2}{|c|}{ Plaxis 8.2} \\
\hline 0 & 1.16 & Critical & 0.92 & Fail \\
\hline 25 & 1.11 & Critical & 0.91 & Fail \\
\hline 50 & 1.05 & Critical & 0.92 & Fail \\
\hline 75 & 1.00 & Critical & 0.93 & Fail \\
\hline 100 & 0.95 & Fail & 0.89 & Fail \\
\hline \multirow{2}{*}{ Infilling $(\%)$} & \multicolumn{4}{|c|}{ Seismic condition } \\
\hline & \multicolumn{2}{|c|}{ Barton criterion } & \multicolumn{2}{|c|}{ Plaxis 8.2} \\
\hline 0 & 1.00 & Critical & 0.88 & Fail \\
\hline 25 & 1.00 & Critical & 0.85 & Fail \\
\hline 50 & 0.91 & Fail & 0.88 & Fail \\
\hline 75 & 0.87 & Fail & 0.87 & Fail \\
\hline 100 & 0.83 & Fail & 0.82 & Fail \\
\hline
\end{tabular}

The stress distribution from Plaxis analysis shows that the potential cracking of the upper part of the hanging rock structure which indicated by concentrated tension stress, while there is no indication of shear stress mobilization in the discontinuity plan.

\section{CONCLUSIONS}

The field investigation and laboratory test suggest that the presence of infilling in discontinuity plan could highly affect the stability the rock slope. However, the finite element model suggested that potential failure is originating from the intact rock body instead of the plane of discontinuities. Therefore, the mitigation action should consider the whole notch structure and the rock joint as well, especially on seismic condition which could dramatically reduce the stability of the slope.

\section{REFERENCES}

Budetta, P., 2004. Assessment of Rockfall Risk Along Roads. Natural Hazards and Earth System Sciences, pp. 71-81.

Canuti, P. et al., 2008. Rockfalls in the Cliff of Pitigliano (Central Italy): Integrated Techniques for Landslide Hazard Assessment. Tokyo, United Nations University.

Hoek, E., Carranza-Torres, C. \& Corkum, B., 2002. Hoek-Brown Failure Criterion. Canada, NARMSTAC, pp. 267-271.

Illiyin, O. A., 2017. Analisis Stabilitas Lereng Batuan Dengan Kritera Barton Dan Metode Elemen Hingga [Stability Analysis of Rock Slope by using Barton Criteria and Infinite Element Method], Yogyakarta: Master Thesist. Department of Civil and Environmental Engineering. Universitas Gadjah Mada.

Jatmikotomo, A., Wilopo, W., Kartika, J. \& Wisnumurti, L., 2015. Resiko Kerentanan Jatuhan Batuan di Pantai Selatan Gunung Kidul, Daerah Istimewa Yogyakarta [Risk of Rock Falls in South Coast of Gunung Kidul Regency, Yogyakarta Province]. Yogyakarta, Universitas Gadjah Mada, pp. 693-703.

Kusuma, W., 2015. Tebing di Pantai Sadranan Runtuh, 10 Turis Tertimbun. [Rock Cliff Fallen at Sadranan Beach, 10 Tourists Burried]. [Online] Available at: regional.kompas.com [Accessed 25 Aug 2017].

Peng, X., Cheng, L., Huang, B. \& Chen, Z., 2008. Distribution of Dangerous Rockmasses and High Steep Slopes in Three Gorges River Valley. Tokyo, United Nations University.

Varnes, D. J., 1978. Slope movement types and processes, Washington D. C: Transportation and Road Research Board, National Academy of Science.

Yuwono, M., 2015a. Cerita Ahmad 1,5 Jam Tertimbun Material Tebing Ambrol [Ahmad's Story 1.5 Hours Burried under Fallen Rocks]. [Online] Available at: News.okezone.com [Accessed 18 March 2016].

Yuwono, M., 2015b. Tebing Ambrol Di Pantai Sadranan Berpotensi Terulang [Fallen Rock Cliff at Sadranan Beach has Potential to be Repeated]. [Online]

Available at: News.okezone.com 
[this page intentionally left blank] 